\title{
Construction Technology of Frame Shear Wall Structure in Construction Engineering
}

\author{
Hailong Zhang \\ Xijing University, Xi'an, 710123, China \\ Email: 24059343@qq.com
}

\begin{abstract}
In the construction engineering application, frame shear wall structure engineering construction technology can simplify the complex construction steps, and improve the overall quality of the building, to ensure the use of performance. Along with the construction of the construction engineering structure gradually become more complex, and the application of the construction technology of the frame shear wall structure is also have a lot of problems. Frame shear wall structure is a common structural type in architectural engineering. This paper introduces the construction technology of construction engineering frame shear wall construction technology, hoping to improve the level of construction unit construction. Brick concrete structure frame shear wall structure compared with the traditional has more advantages with its anti deformation capacity and higher stability. In the application of the process can improve the safety of the building. The construction technology of the frame shear wall structure is more complex in the process of the application needs to do a detailed work, but also combined with the engineering practice to improve and optimize the construction technology, so as to ensure the construction quality of the construction project.
\end{abstract}

Keywords-Construction engineering; frame shear wall ;construction technology; analysis; structural engineering

\section{INTRODUCTION}

With the continuous development of construction technology, the frame shear wall is an important technology in engineering construction projects, it gradually gets more and more attention. In building construction, the frame shear wall structure can not only improve the construction quality, but also make the building more stable, reduce the cost, save a lot of construction materials. In the process of construction, the frame shear wall should be combined with the project, according to the actual situation, to develop a set of construction plan, so that we can improve the efficiency and quality of construction.
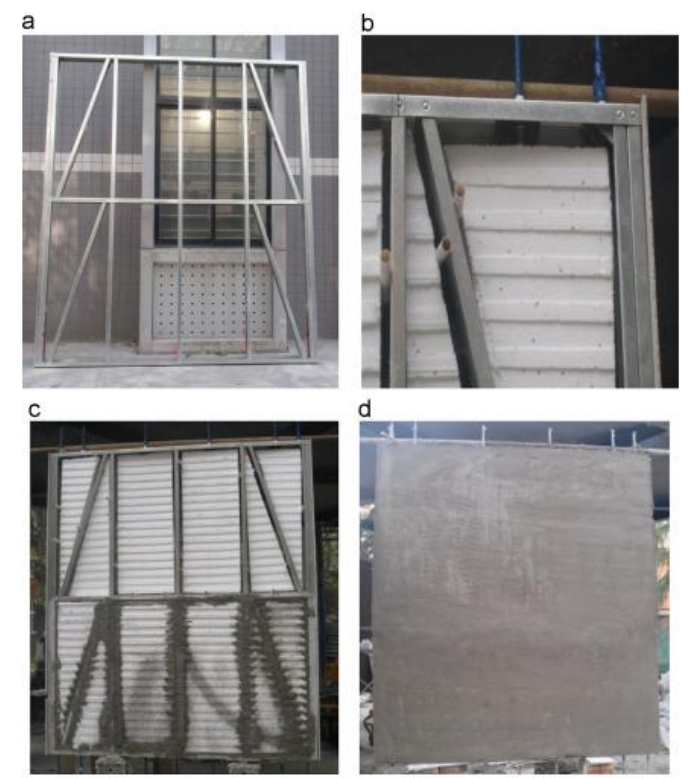

Figure 1. shear wall structure

\section{OUTLINE OF FRAME SHEAR WALL STRUCTURE}

\section{A. Concept of frame shear wall structure}

The frame shear wall structure is based on the frame structure, and the structure of the bearing system is optimized. The frame structure is a frame which is formed by the beam and column connection, which can share the load of the building, and has the function of the building envelope and the separation. This structure has the advantages of flexible arrangement, but the nodes in the framework of stress concentration, which leads to its lateral stiffness is relatively small. And it is not suitable for high rise building in the high-rise building. It has a good application prospect, and it is the inevitable trend of the development of the construction industry in the future. Architectural design personnel must improve the traditional frame structure, so as to ensure the stability of high-rise building structure. Shear wall structure is formed by the combination of shear wall, can bear the vertical and horizontal load, this structure can also ensure that the construction space is more spacious, can guarantee the building interior space of open. Shear wall structure has some disadvantages, its flexibility is relatively poor, is not easy to dismantle, and can not be achieved in the space of free layout. Frame shear wall structure is a new type of structure. It combines the advantages of frame structure and shear wall structure, and achieves the advantages of complementary. Not only has high bearing capacity, but also has high flexibility, it has the characteristics of simple 
operation, convenience, etc., the frame shear wall structure in the application of the process has received a good effect.

\section{B. Characteristics of frame shear wall structure}

In order to analyze the structure of the frame shear wall structure, the structural characteristics of the frame should be understood first. Frame shear wall structure has three main characteristics, the force, stiffness, seismic namely .

The stress characteristics of the frame shear wall structure. Frame shear wall as a cantilever beam with a vertical surface and an empty stomach, the structure is often subjected to various pressures, bending deformation, and the deformation curve is a bending shear type.

Frame shear wall structure stiffness characteristics. In general, when the frame shear wall structure of the force performance is close to the pure frame structure, that is, the base moment about $20 \%$ of the total moment, the frame stiffness will be affected, you should set up the corresponding seismic grade. When the base moment is about $80 \%$, the frame stiffness is close to the minimum, so we should take reasonable and effective structural measures to carry out seismic shock absorption.

Seismic characteristics of frame shear wall structure. The main basis for determining the seismic grade of the frame shear wall structure is the <seismic design code> and <the design and construction of the reinforced base high-rise building structure $>$.

Is the ratio between the stiffness of the shear wall and the stiffness of the frame. By understanding the characteristics of the frame shear wall structure, it can provide the necessary foundation and direction for the study of the construction technology, and provide the corresponding guidance.

\section{3 ASPECTS OF FRAME SHEAR STRUCTURE IN CONSTRUCTION PROCESS}

In the process of building construction, in order to comply with the national introduction of the frame structure and the relevant policies, the construction team in the process of construction must first develop a scientific and reasonable plan, the design scheme of the paper content by the special unit audit, audit can begin construction. No matter how high buildings, in the construction of the project should pay attention to 3 aspects of the requirements.

The overall structure of the project construction, the frame shear wall is generally to maintain the original structure of the premise of the use of design and construction technology, to optimize the structure of the system can not only improve the quality of the construction, but also to ensure the structural integrity, the problem can be appropriate for the construction process.

Reinforced concrete structure design and construction of reinforced concrete structure because of the weight, size, difficult to change and so on, so in the construction must first detailed analysis of the frame structure parameters and construction parameters, to deal with potential problems, so as to avoid the construction process can not meet the requirements.

in general, the design of shear wall structure and the calculation of the shear wall, not only need to carefully analyze the key points, but also to analyze and summarize the framework and shear wall model, so that the two can cooperate with the tacit understanding, improve the work efficiency, maximize the role of their own.

\section{3 TECHNIQUES USED IN THE CONSTRUCTION OF FRAME SHEAR STRUCTURE}

\section{A. line measurement technology,}

The project construction team in the construction of the project, the construction team in the construction team, must be in accordance with the engineering design drawings and the relevant provisions of the measurement. Scientific and reasonable use of professional wire measurement equipment in order to complete the line measurement technology.for example, for the frame shear wall structure, the use of instrument with theodolite or total station, construction team in the measurement process, the need to build up the control network, the actual measurement of the control line to make a mark. In order to ensure the accuracy of the construction team put line measurement, it should be a special person to put all the results of the measurement of the line carefully checked repeatedly to avoid unnecessary mistakes.

\section{B. Steel construction technology}

As an important part of the construction project, the construction of reinforced construction materials important positions, the same is also reinforced in the construction process. In the construction of the frame shear wall, the steel bar material must meet the requirements of the standard, and the reinforced material must also be equipped with the relevant requirements of the material report. In the construction of frame shear wall, construction technology requirements of steel and reinforced lap lap length, position of welding way to meet the bar, so as to ensure the quality of construction steel construction! In the construction process of the frame shear wall structure, should use precast mortar as each supporting point of lashing the main reinforcement, make it become stronger, to ensure that the construction process of steel does not appear quality problem. Construction process of reinforced frame shear wall, reinforced lap technology professional has two kinds, respectively is the welding technology of banding lap technology and electro slag pressure welding, in the construction process, according to the actual situation of the steel construction to choose the appropriate method from between the two. Suitable for the construction of the implementation of the construction of the steel reinforcement in the implementation of the construction process, the technology must meet the relevant standards and requirements, so as to ensure the construction of steel in the construction process of quality. The process of steel construction in frame shear structure, joint column stirrup arrangement should be staggered arrangement, the corner intersection of vertical reinforcement and stirrup, to ensure that they are in a vertical state when the shear structure construction! In the box, for column encryption stirrups construction binding. According to the actual situation of the construction of reinforced, choose to meet the requirements of the technology of the lashing lashing. Frame shear wall project construction engineering reinforcement construction technology of an indispensable 
part in the construction process of reinforced technology, according to the relevant provisions and requirements to implement, to ensure the construction quality of all steel and steel the standards are in accordance with the relevant standards, so as to ensure the quality of the frame shear wall in the construction process.

\section{Concrete engineering}

In the construction process, the concrete project is in a very important position, and the frame shear wall structure and stiffness are closely linked, in order to improve the concrete engineering construction quality, prolong the life of concrete, general need to pay attention to this point: First, the most important step is to reconcile the configuration concrete, with a certain proportion into the required material, this is very important, if the proportion of the right, may be in the actual construction collapse, the construction workers; Second, pouring concrete, pouring sequence is very particular about. Usually choose different concrete strength grade pouring method, the bottom pouring concrete, it has higher strength and higher level, can increase the strength of the bottom, and then in the bottom of the concrete, it is relatively low level. By placing two layers of different grade of concrete, it can ensure the quality of concrete engineering. There is a practical casting method is layered pouring, pouring it is suitable for large section beam, in order to ensure the density of concrete, various materials need to vibrating compaction; Third, the completion of the initial mixed concrete engineering construction. Professional needs for maintenance of new concrete, to carry out professional sprinkler maintenance according to the situation of the construction site to ensure the damp, wet surface construction site pouring concrete, the wetting time of not less than $7 \mathrm{~h}$.

\section{CONSTRUCTION TECHNOLOGY ANALYSIS OF FRAME SHEAR WALL STRUCTURE}

For the construction technology analysis of the frame shear wall structure construction engineering, the concrete construction of the frame shear wall structure is the case, from the frame shear wall structure of the construction engineering construction, the frame shear wall structure construction engineering technology analysis.

\section{A. Measurement technology of the frame shear wall structure building}

First of all, according to the construction design drawings, construction engineering construction survey of the relevant requirements for the implementation of the relevant requirements, attention to the application of advanced measurement instruments for the measurement of the construction of the project. For example, in the process of building the frame shear wall structure building engineering in the process of measurement, the total station or theodolite and other measuring instruments. In the construction engineering of the measurement, the attention to the establishment of the construction of the line measurement axis control network, according to the measurement of the line to mark.

\section{B. Frame shear wall structure construction technology}

Steel construction is an important part of building construction, steel is also an important construction of construction materials used in construction. In the construction of the frame shear wall structure, the reinforced materials used in the construction engineering construction should be in accordance with the construction standards, and there is a perfect test report of the reinforced materials. In the construction of the frame shear wall structure, the construction of the reinforced bar and the overlap length and the position and the welding method should be in accordance with the construction requirements of the frame shear wall structure. In addition, in the construction engineering construction of reinforced frame shear wall structure, the main reinforcement construction should pay attention to the use of prefabricated mortar bandage firmly, to ensure the construction quality of steel.

The frame shear wall structure construction of reinforced construction, steel lap construction technology mainly electroslag pressure welding technology, banding lap technology.In the construction according to the specific circumstances of building engineering construction of reinforced bar, you can use different lap technology or construction implementation type. For construction engineering reinforcement of the overlap construction must comply with the relevant requirements and standards, in order to ensure the construction quality of construction projects. The frame shear wall structure construction of reinforced construction, for the construction of reinforced column stirrup joints in the construction of the arrangement of attention should be arranged in accordance with the method of staggered intersection, for construction and construction of vertical reinforcement stirrup angle should keep vertical. The frame shear wall structure construction column joint stirrup binding construction, construction engineering construction should be based on the steel frame shear wall structure, binding binding process appropriate choice of construction. In the construction of this part, we should pay attention to strict accordance with the construction requirements and standards, ensure the construction of the steel material quality and the model in line with the construction standards, to ensure the construction quality of the frame shear wall structure.

\section{Frame shear wall structure building concrete construction technology}

Construction engineering concrete construction part of the construction engineering construction is an important part of the frame shear wall structure construction engineering construction is in the construction of steel and 


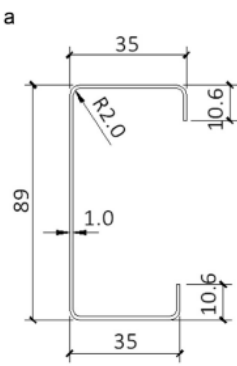

b
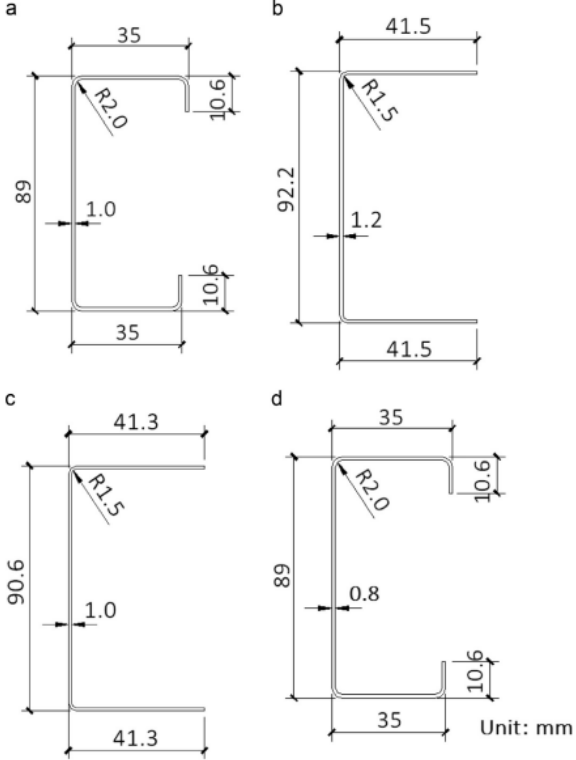

Figure 2. Cross-sectional dimensions of frame members

formwork construction end and acceptance. According to the construction of a frame shear wall structure, the concrete construction of the building works mainly refers to the construction of the wall column structure and beam slab. The concrete pouring construction method is carried out, which is different from the construction conditions, so that the construction technology and method of concrete pouring in different construction are also different.

\section{CONCLUSIONS}

Along with the continuous development of science and technology, many new construction materials and advanced construction technology emerged in the modern construction engineering. The frame shear wall structure engineering construction technology is the most widely used in modern urban construction technology, which can improve the quality of the whole building, and to ensure the construction personnel and the construction of the security, and meet the needs of the owners of the building. However, there are still many problems in the construction technology of the frame shear wall structure, such as the construction of the construction engineering, there are some problems not resolved. However, with the application of construction technology in construction engineering, the construction technology of the frame shear wall structure is becoming more and more perfect.

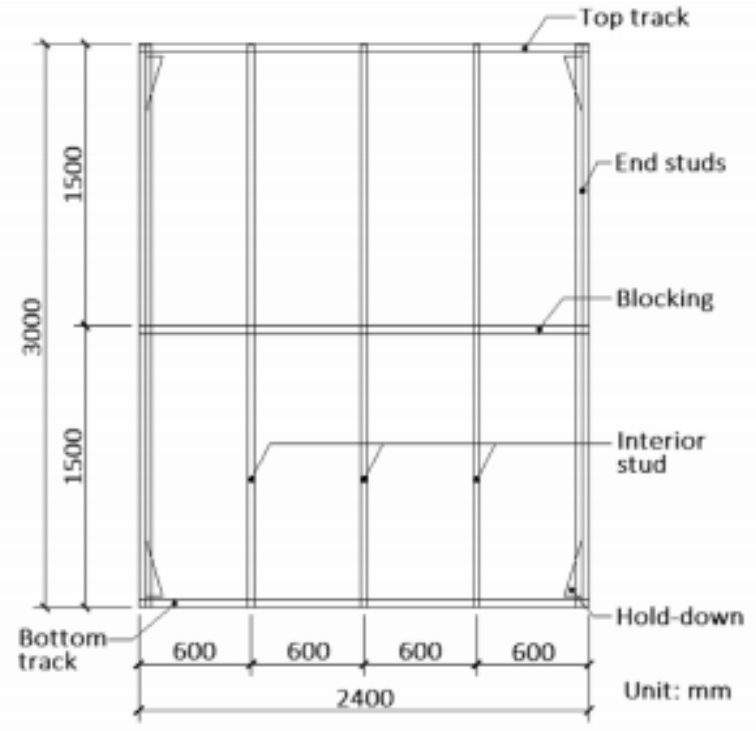

Figure 3. Configurations of frames

\section{REFERENCES}

[1] C.L. Pan, M.Y. Shan, Monotonic shear tests of cold-formed steel wall frames with sheathing, Thin-Walled Struct. 49 (2) (2011) 363-370.

[2] M. Nithyadharan, V. Kalyanaraman, Behavior of cold-formed steel shear wall panels under monotonic and reversed cyclic loading, Thin-Walled Struct. 60(11) (2012) 12-23.

[3] P. Liu, K.D. Peterman, B.W. Schafer, Impact of construction details on OSB-sheathed cold-formed steel framed shear walls, J. Constr. Steel Res. 101 (2014)114-123.

[4] M. Zeynalian, H.R. Ronagh, Seismic performance of cold formed steel walls sheathed by bre-cement board panels, J. Constr. Steel Res. 107 (2015) 1-11.

[5] M. Zeynalian, H.R. Ronagh, A numerical study on seismic characteristics of knee-braced cold formed steel shear walls, ThinWalled Struct. 49 (12) (2011)1517-1525.

[6] M. Zeynalian, H.R. Ronagh, S. Hatami, Seismic characteristics of K-braced cold-formed steel shear walls, J. Constr. Steel Res. 77 (10) (2012) 23-31.

[7] M. Zeynalian, H.R. Ronagh, An experimental investigation on the lateral be-havior of knee-braced cold-formed steel shear walls, Thin-Walled Struct. 51(2) (2012) 64-75.

[8] O. Iuorio, V. Macillo, M.T. Terracciano, T. Pali, L. Fiorino, R. Landolfo, Seismicresponse of Cfs strap-braced stud walls: experimental investigation, Thin-Walled Struct. 85 (2014) 466-480.

[9] V. Macillo, O. Iuorio, M.T. Terracciano, L. Fiorino, R. Landolfo, Seismic response of CFS strap-braced stud walls: theoretical study, Thin-Walled Struct. 85(2014) 301-312.

[10] L.G. Vigh, A.B. Liel, G.G. Deierlein, E. Miranda, S. Tipping, Component model calibration for cyclic behavior of a corrugated shear wall, Thin-Walled Struct.75 (2) (2014) 53-62.

[11] W. Mowrtage, N. Hasan, B. Pekmezci, H.N. Atahan, Loading carrying capacityenhancement of cold-formed steel walls using shotcreted steel sheets, Thin-Walled Struct. 60 (11) (2012) 145153 